UDC: $528: 37.035 .3$

DOI: $10.14438 / \mathrm{gn} .2015 .06$

Typology: 1.04 Professional Article

Article info: Received 2015-03-18, Accepted 2015-03-30, Published 2015-04-10

\title{
Geodetic Education and Practice in the Republic of Serbia - Past and Present
}

\author{
Dragana MILIĆEVIĆ SEKULIĆ ${ }^{*}$, Olga RAKOČEVIĆ ${ }^{2}$, Branko BOŽIĆ ${ }^{1}$ \\ ${ }^{1}$ University of Belgrade, Faculty of Civil Engineering, Belgrade, Serbia \\ ${ }^{2}$ Republic Geodetic Authority, Požega, Serbia
}

\begin{abstract}
Development of geodetic education and practice was accompanied by changes in the development of society. Country isolation at the end of $20^{\text {th }}$ century had a huge influence on surveyors practice in Serbia. The beginning of $21^{\text {st }}$ century brought democratic changes, membership in European Union as an important goal, and, generally, opening the society for changes in many spheres.

The most important changes in the field of geodesy were reform of educational system, establishment of real estate cadastre and realization of projects through international cooperation. These changes created an opportunities for employing surveyors in many new areas. Today, a lot of geodetic experts work on positions where it has not been possible before. This paper describes employment opportunities for Serbian surveyors and explains the experience in doing surveying at the Serbian market that have been obtained so far.
\end{abstract}

Keywords: education, education reform, geodetic profession, employment opportunities

*Dragana Milićević Sekulić > dmilicevic@grf.bg.ac.rs 


\section{Introduction}

The last decade of the $20^{\text {th }}$ century in Serbia was marked by disintegration of the Former Yugoslavia, war, poverty, economic collapse, high inflation rate and isolation due to international sanctions. The circumstances in which the country found itself in caused a general stagnation in the areas of economy, technology and science. This trend was most clearly reflected in the gap in technological development and did not bypass geodes. In the year 2000 , over a decade later than in other post-communist countries, socialist political system was replaced by democracy with strong inclination for further socio-economic development and aspirations to join the EU. This goal implies a series of conditions that a candidate country must fulfill, along with a number of structural changes that need to be implemented in all institutions of the government.

The modernization of the legal system caused by reformation of existing and adoption of new legal regulations allowed access to foreign investors and banks. All of these changes can be observed from different points of view, but the fact remains that Serbia has untapped natural resources, inexpensive workforce and great potential for investments. In addition, Serbia has a large number of well trained professional workers that have been leaving the country for decades due to unemployment or low wages. This is a troubling state of affairs and it is necessary to implement measures which will give young people the opportunity to stay and create a life for themselves in their home-country. Opening the country to foreign investors would resolve the problem of unemployment and create the conditions for economic development and scientific progress.

\section{The changes in the field of geodesy}

Changes in geodesy in Serbia that occurred in the $19^{\text {th }}$ century have been caused by changes in the education of geodetic professionals and economy. The new millennium has brought new challenges and opportunities for employment not only in narrowly specialized professional areas.

Still, there are many areas in which the necessity for hiring geodetic experts has not yet been considered.

\subsection{Changes in the education system for geodetic professionals}

The organized system for higher education of surveying staff in Serbia was formed in 1935. Over the past 77 years, this type of higher education passed through various stages. At the beginning it was mostly based on the knowledge and experience of experts trained in German and Austrian universities. The situation changed quickly, and fewer and fewer teachers were educated abroad.

Higher education in the field of geodesy in Serbia can be acquired at three academic institutions:

- University of Belgrade - Department of Geodesy and Geoinformatics, Faculty of Civil Engineering in Belgrade,

- University of Novi Sad - Department of Geodesy and Geomatics, Faculty of Technical Sciences in Novi Sad, and

- College of Applied Sciences of Civil Engineering and Geodesy in Belgrade Department of Geodesy and Geomatics in Belgrade.

Apart from these institutions, it has to be mentioned that a significant number of experts who work in both civil and military sector were educated at the Military Academy in Belgrade. In the years after World War II the higher education in the field of geodesy could also be acquired at the Army officer school. From 1953 military trained its geodetic personnel at the Geodetic officer school, then, until 2000, at the Military Academy, when the last class of officers-geodetic specialists was enrolled. During this time the number of officers enrolled into the geodetic program varied. In the first decades there were a large number of officers getting educated in the field of geodesy but the number decreased over the years until 2005 when military finally stopped its geodetic educational program. This was caused by the shrinking of the country's territory and decreased demand for geodetic professionals. This poses a serious question whether Ministry of Defence has the ability to maintain the Military Geographical Institute as the main military facility for performing geodetic activities [1].

\section{History of higher education in Serbia}

In 1834, Miloš Obrenović, Prince of Serbia announced a decree by which the "High School" in Kragujevac (state capital at the time) was to become a college with a purpose of educating technical professionals which the newly formed country lacked. The first rector was Atanasije Nikolić, a geodetic expert. The college was quickly formed and in $1837 / 38$ its professors started teaching several general courses comparable to studies of philosophy. One of the courses was practical geometry, at that time a term 
used for what we now call geodesy. It was immediately apparent that adequate teaching staff cannot be found in a country where the majority of people were still illiterate and that teachers must be acquired abroad. In 1840, the college was moved to Belgrade which was better connected to European university centres and was, as a new capital city, undergoing planned urbanization.

The college was initially envisioned as an extension for the six year high school program, but in 1863 the college was transformed into the "High School" or a University. The "High School" taught technical and general education courses, but quite quickly, in 1875, the "High School" High Academic counsel proposed the educational reform which was supposed to introduce new courses and structure to the university, including formation of the geodetic department. After the adoption of legal reforms in 1880 , the term geodesy replaced the term practical geometry.

In 1897, the technical college was divided into three departments: Construction and Engineering, Architecture, and Mechanical Engineering. Since then, geodetic education is taught at the School of Civil Engineering [7]. The state geodetic authority was formed in the same year and all geodetic courses taught at the Construction and Engineering Department were required to provide practical education.

Higher education in Serbia was further improved with the adoption of Law on University and the formal formation of the Belgrade University in 1905 when all departments became independent colleges [7]. The geodesy group was formed in 1935 at the College of Civil Engineering, and in 1947, it became the geodesy department. This allowed the students who graduate at this department to gain the title of "Geodetic engineer" [7]. From time to time, new courses were deemed necessary for education of new geodetic engineers or were developed from existing areas of expertise that were added to the curriculum.

\section{Education reform}

The basic education model on the geodesy department of the Faculty of Civil Engineering in Belgrade has practically remained the same but the courses changed the way they were organized over last 65 years. The studies used to last four years, than five. Students from all civil engineering departments used to take same courses for the first two years after which they took more specialized courses. There was also a two year study program after which a student would get a degree equivalent to a trade or vocational school diploma (today a student can earn such a degree at the College of Applied Sciences of Civil Engineering and Geodesy). Since 1960 geodetic education could also be acquired at College of Applied Sciences of Civil Engineering and Geodesy in Belgrade [3], and since 2007 at the University of Novi Sad - Faculty of Technical Sciences [4]. During the years all these institutions changed their curriculums to meet industry demands.

The last and probably the most influential geodetic department curriculum reforms were adopted in 2001, after 15 years of isolation due to economic and political sanctions. This general education reform was aimed to increase study programs efficiency on all universities in Serbia. The efficiency of a study program was considered low if students need more then nominal period of time to complete a program, if students fail their courses, if students require more than one academic year to complete a course or if the percentage of students who graduate was below of expectation. All above mentioned low efficiency parameters were present on all universities in Serbia. On average, 7,51 years were required for the completion of a five year study program (counting only students who graduated), $45 \%$ of enrolled students dropped out before graduation, on average, 1,45 years were required for completion of all courses in one academic year and almost $46 \%$ of students had to repeat the whole second year of their studies program [6]. The most common reasons for this state of the education system are overworked students and rigid academic system [6]. However, the reasons for this kind of inefficiency of the education system can be divided into two groups: systemic (institutional) and extra-systemic (individual, family, social). All this prompted the need for reforms along with the fact that our education system greatly differed from the education systems in developed countries.

Since October 2005, a new curriculum, based on provisions of the Bologna Declaration, was used in the geodesy and geoinformatics department at the Belgrade University Faculty of Civil Engineering. The new structure of the academic program divides the geodesy study program into three degrees: Bachelor (BSc), Master (MSc) and Doctoral (PhD). The new element is the introduction of modules in the master studies. Since the academic year 2008/09, students were, at the beginning of their master program, given a choice between two modules, geodesy or geoinformatics, and in 2009/10, module land management was also introduced [2]. 
Undergraduate studies have been changed again in $2008 / 09$ and in 2014/2015 in order to correct deficiencies of the earlier curriculum.

The Faculty of Technical Sciences in Novi Sad was founded in 1960 and provides students with opportunity for higher education in areas of geodesy and geomatics from $2007^{\text {th }}$. The study program in this college is divided into three degrees: BSc, MSc and $\mathrm{PhD}$. The difference between this program and the program at the Faculty of Civil Engineering of Belgrade University is program structure. Here undergraduate studies lasting four years and one additional year for master studies while in Belgrade the undergraduate studies lasting three years and two additional years for master studies, along with the possibility to continue master studies of geodesy or geomatics in the [4].

Higher School for Civil Engineering - Geodesy was also formed in 1960. This school also underwent reforms to adjust its study program with the provisions of the Bologna declaration.

The three year geodesy-geomatics study program has two specializations: applied geodesy and state survey and cadastre. After the completion of undergraduate studies students have an option to enroll into the additional one year specialization program [3].

Conducted reforms and efforts invested into the formation of new study programs shows the willingness of teaching staff to improve and acquire new skills while developing much broader cooperation with other European universities. The primary goal of the education reforms was to provide professionals for the Serbian job market, but also to guarantee that our professionals are competitive in the international job market.

\subsection{Changes in the economy}

Development of geodetic market in Serbia was often influenced by social circumstances and varying influx of capital. There are two distinct periods in the development of geodesy related business. The first period lasted from the beginning of geodetic activities in Serbia until 2002 when revised Law on State Survey, Cadastre and Registration of Real Estate Rights was adopted. The second period covers the time after the adoption of said Law. The main difference between these two periods is the structure of owner's capital. Until 2002, geodetic activities were performed exclusively by state owned companies or companies not primarily registered for performing these activities. After 2002, this changed because the scope of geodetic activities that could be performed by privately owned geodetic companies, was legally prescribed. This liberalized the market for geodetic activities allowing formation of private geodetic companies and their prosperity.

\section{Geodetic practices before 2002}

Development of geodesy in Serbia started in 1837 when Prince Miloš Obrenović began tackling the issue of cadastral surveying and land classification. From that point until 1918 efforts were made to create a survey and cadastre system. Geodetic surveying of Serbia during that period was predominantly performed by officers from Viennese Military Geographical Institute. Serbian military authorities adopted this survey data and, in 1876, initiated formation of the General Staff's Geographical Department and the establishment of Serbian Military-Surveying Service.

Civilian authorities established control over records on immovable property and property rights in 1919 when General Cadastre Directorate was established as a part of Ministry of Finance.

Another significant year for the development of state geodetic service was 1947, when State Geodetic Administration of Republic of Serbia was established. Since then, this administration was an integral part of the ministry in charge of state finances, but was also occasionally structured as an independent state authority.

Intensive work on establishment of a geodetic network and state survey in Serbia started in 1921. State survey was completed in 1977, prompting a period of intensive land consolidation process. In addition to the working in the State Geodetic Administration and Military Geodetic Service, a large number of surveyors simultaneously worked in the area of geodetic engineering (around 45\%). This significant number of geodetic professionals worked in project and design studios, construction and investment companies. Increased volume of capital construction projects, both in country and abroad, after the World War II, played a significant part in the development of geodesic engineering.

After the World War II, the authorities started an ambitious reform of the State Geodetic Administration. The period between 1945 and 1987 was characterized by ambitious plans and increased demands from the authorities on one side and lack of technical equipment and instruments on the other. This period was characterized by a tendency to decentralize administration, which resulted in uneven 
development and maintenance of records, and the neglectful attitude towards basic geodetic activities. In addition, Socialist Federal Republic of Yugoslavia (SFRY) membership in the International Union of Geodesy and Geophysics was intermittent due to inactivity and the nonpayment of dues.

The period after 1976 is characterized by extensive preparation for the unification of all property records kept in the land registry and cadastre, which was not legally regulated until 1988. This model is considered to be reasonable and dependable, and the retrieval of cadastre data efficient and reliable.

Republic Geodetic Authority (RGA) as it exists today, was formed in 1992, by consolidating the Republic Geodetic Administration, municipal geodetic departments and almost all surveying companies. In 1992 the RGA had approximately 3.500 employees, which included nearly all of surveying personnel in the country. RGA experienced significant personnel reduction in 2002 when new legal provisions allowed private companies to perform certain surveying and cadastral maintenance procedures. Since then, a variety of surveying companies and organizations, whose number is quite difficult to determine, have been formed in Serbia.

The period between 1995 and 2001 was characterized by a large number of projects of strategic importance for the State. Since 2001, after the changes in the political and social system in Serbia, conditions for new economic development have been created. There is a need for more intensive development and application of new technologies. The future development of geodesy is aimed at the expanding role of the private sector, establishment of an efficient cadastre, implementation of new technologies, and staff and public education.

\section{Geodethic practices after 2002}

New phase in the development of Republic Geodetic Authority and geodetic activities in general, started in 2002, when a donor conference initiated a number of development projects financed by donor countries, and aimed to improve staff and technological capabilities of the RGA. One of the largest and most important projects was the "Cadastre and real rights register in Serbia project" which was financed by World Bank, GTZ, SICAD Geomatics, and Norwegian, Austrian, Japanese and Swedish governments. Apart to this project, which was completed in 2012, other projects, were also implemented.

Some donor projects aimed to improve the working conditions for employees, while others were implemented in order to meet the demands of business owners and citizens for greater efficiency in public administration. Among the most important projects, establishing new AGROS GPS permanent stations network, and creating corresponding software for its control center, formatting digital archive, mortgage system, mass appraisal system of real estate market values, the introduction of geo-portal and many others were done. The development and application of new technologies required a high level of education and accumulated professional experience.

Gaining professional experience was enabled through training, workshops, seminars, study visits, and through conducting pilot projects. For further development of geodesy in public administration, it is necessary to provide continuous education of employees and to ensure the sustainability of the achieved results and an upgrade of accomplished achievements.

Changes in the economy required changes of legal regulations. In order to eliminate the problems and shortcomings in the implementation of the existing legal framework, the Serbian Government adopted the Law on State Survey and Cadastre in 2009 [8], whose provisions introduced a number of new possibilities in regards to surveying activities. This law created a basis for the National Geospatial Data Infrastructure, prescribed mandatory formation of cadastral information system defined by the transition to the new national reference system which is in line with the European reference system, and introduced mass appraisal procedures. It also introduced provisions aimed at creating more orderly environment with regards to organization and human resources management of private geodetic companies. At the same time, The Geokarta - Institute for Cartography and Republic Geomagnetic Institute were attached to the RGA.

Development of geodesy in military continued along with the development of geodesy in the civilian sector. The largest numbers of surveyors working for the military are employed in The Military Geographical Institute, a descendant of The General Staff Geographical Department. A smaller number of surveyors are employed in other departments at The Ministry of Defense.

The Military Geographical Institute is an institution which is engaged in research, development and manufacturing operations in the areas of geodesy, photogrammetry, cartography, geographic information systems and other surveying disciplines. 
In the period between 1945 and 2000, various military schools have trained 760 experts of all surveying profiles, who used their expertise performing various tasks for the military, legal and physical persons as well. The future of The Military Geographical Institute is in question because of significant disadvantages in planning. The scope of required projects and the number of trained personnel were not correlated, that caused the cancelation of the military geodetic study program in 2000 [1]. In addition, the fact that this profession required training work abroad has for a long time been ignored.

\section{Employment opportunities for geodetic professionals}

Geodetic profession is one of the oldest technical professions in Serbia. Employment opportunities for surveying personnel in Serbia are numerous, and generally can be divided into:

- public sector entities,

- private sector entities.

The public sector entities are all organizations that use terrain information, maps and databases of real estate: RGA, government institution, state owned companies with various engineering departments etc. Surveying staff in Serbia is usually employed in governmental agencies which are responsible for the surveying, formation and maintenance of real estate records. At the time when the RGA was established (in 1992), it employed almost all geodetic professionals in the country. Few surveyors were employed in larger state-owned enterprises who needed this type of staff, but whose primary activity was not geodesy. A lot of surveyors were employed in educational and military institutions. Over time, the number of employees in state administration decreased, while the private sector created and steadily increased its number of employees.

In addition to The RGA, which employs the largest number of surveyors, municipal urbanism departments also require geodetic professionals. Almost, every local urban planning department employs at least one geodetic expert. The reason for this is the nature of jobs that are surveying experts trained to do, and which are related to the management of maps and plans.

One of opportunities for employment of geodetic staff are state institutes and agencies in charge of forest and water management, mining of mineral resources, energy distribution and so on. The possibilities are numerous because all these institutions rely on maps and plans in order to carry out their activities. The benefit that these organizations can gain through employment of geodetic professionals is immense, but it seems that not everyone is aware of this fact.

The private sector entities include private surveying companies, distributors of surveying equipment and companies where surveying is a secondary activity. After the change of legal provisions in 2002 which created conditions for the formation of private enterprises, there was a reduction in the number of employees in the Republic Geodetic Authority compared to the number of geodetic professionals employed in private sector. The work was divided and so the Republic Geodetic Authority took over the task of establishing a real estate cadastre and private land surveying organizations executed field operations and procedures. Once the legal basis for operation of private geodesic companies was created, very rapid restructuring of surveying enterprises followed. In 2002 there were 92 private geodetic enterprises with 500 employees. In 2008 this number increased to 631, and the number of employees to 2000. The largest increase in the number of newly registered private surveying companies was in 2002 and 2003. When it comes to the type of registered entities, the number of individual entrepreneurs is far greater than the number of companies, except in Belgrade, where the situation is reversed [5]. According to Licence register of Republic Geodetic Authority on date $26^{\text {th }}$ March 2015, 467 geodetic private offices had a licence for work [9].

Along with increasing in the number of private geodetic companies, there was also increasing in number of companies involved in importing and distributing surveying equipment. The increasing in the number of these companies is noticeable after 2000. In order to make the work process more efficient, along with surveying equipment, various software solutions were required. So, in addition to distribution of equipment, a large number of these companies were engaged in the distribution of software written for a variety of surveying tasks. A large number of surveyors, especially the younger generation, are employed with companies that procure tools, service equipment, perform training and provide technical or other support.

Apart from imported software for data processing, there are several Serbian software development companies which successfully created software for a number of uses in geodetic activities. Educational institutions have recognized the 
importance of software development and the importance of experts knowledgeable in both geodesy and programming, and established Geoinformatics and Geomatics study programs.

Although the computer cannot replace humans in performing all required tasks, they can be used to speed up time consuming tasks, to reduce the possibility of human error and to increase competitiveness of geodetic professionals in the job market.

The issue that is in the centre of attention both in global world and in Serbia is land management policy and sustainable land management. The land is nonrenewable and finite resource and it needs to be used in a way that will preserve it for generations to come. On the other hand, population growth requires new areas of land to be used for residential and agricultural purposes. Land management policy is trying to find a way to satisfy the needs of the population and to preserve the environment for future generations. Although a lot of the Serbian population is currently struggling with basic existential problems, dedicated individuals have recognized the importance of educating experts who will be educated in geodesy, but also will be able to implement techniques for effective land management. With this in mind, in 2009, several education institutions in Serbia have created study programs dedicated to land management.

The most commonly method used for land development in Serbia is land consolidation. After a decades, long break in use of this method (due to economic reasons), several municipalities in Serbia have recently begun land consolidation projects. Given the lack of developed agricultural land in Serbia, and due to the fact that the consolidation was done mainly in Vojvodina and in the regions near Morava river, land consolidation could represent an important market for the employment of surveyors. Recognizing the importance of these land management measures and allocating sufficient resources for their implementation could significantly increase demand for geodetic professionals.

The arrival of investors and foreign companies in Serbia creates the environment for the employment of experts in various fields who will be working on various projects. Geodetic personnel can become a valuable part of any team when the "task at hand" requires spatial positioning.

\section{Conclusion}

Although the surveying profession in Serbia is one of the oldest, it can't be said to be the most numerous. According to some estimations, the number of geodetic professionals is about 5000. As before, most experts were employed in governmental agencies, while others worked for private geodetic companies. A small number of experts is now working on software development, distribution and servicing of surveying equipment, but employment opportunities for this type of experts are not limited to these. There are numerous governmental agencies and local government institutions that require spatial data for their activities and this represents an opportunity for employment of geodesic professionals. In addition, foreign companies also present employment opportunities but their needs are still not clearly defined.

In the future, in addition to the maintenance of real estate cadastre, which is a priority for the development of the country, we can consider projects related to restitution and land consolidation as largest markets for employment of geodetic professionals. Although the development of these important issues depend on the decisions of state authorities and allocated resources, geodetic personnel remains hopeful that the governmental policies will be directed towards the food production as one of the steps towards correcting decisions made by the authorities several decades ago.

\section{References}

[1]Bakrac, T. S., Tatomirovic, S., Bankovic, D. R. and Borisov, M.(2011) Školovanje i usavrsavanje kadra za potrebe geodetske sluzbe od drugog svetskog rata do danas. Vojno delo, pp 466-478, 2011.

[2] Božic, B. and Raskovic, M.(2008) New master study programme in land law and economy at the Faculty of Civil engineering the University of Belgrade. FIG Working Week 2008., Stockholm, Sweeden, 14-19 June 2008.

[3] College of Applied Sciences of Civil Engineering and Geodesy, Department for geodesy and geomatics: Web page. Retrived from:

http://www.vggs.rs/geodetski_odsek/index.html, 26.3.2015.

[4]Faculty of Technical Science in Novi Sad, Department for Geodesy and Geomatics: Web page. Retrived from: http://www.ftn.uns.ac.rs, 26.3.2015.

[5] Gospavic, Z. and Piperac, D.(2009) Razvoj tržista geodetskih poslova i privatne geodetske prakse u Republici Srbiji. Geodetska služba, Vol. 38, No. 111, pp 20-24, 2009. 
[6] Jaric, I. and Vukasovic, J.(2011) Bolonjska reforma visokog školstva u Srbiji: mapiranje faktora niske efikasnosti studiranja. Filozofija i drustvo, br. 2/2011, pp 119-151, 2011.

[7] Mihajlovic, K.(1987) Geodezija u školstvu Srbije, in "Geodetska delatnost u Srbiji 1837-1947-1987", pp 129-145, State Geodetic Service of Republic of Serbia, Belgrade, 1987.

[8] The Law on State Survey and Cadastre. (2013) Official Gazette of the Republic of Serbia no 72/09, 18/10, $65 / 13$.

[9] Republic Geodetic Authority: Web page. Retrived from: http://www.rgz.gov.rs/reg-go-

public/GeoOrgPublic.aspx, 26.3.2015. 